\title{
IgG Fc engineering to modulate antibody effector functions
}

\author{
Xinhua Wang, Mary Mathieu, Randall J. Brezski ${ }^{\bowtie}$ \\ Genentech, Antibody Engineering, South San Francisco, CA 94080, USA \\ $\triangle$ Correspondence: brezski.randall@gene.com (R. J. Brezski) \\ Received May 30, 2017 Accepted June 19, 2017
}

\begin{abstract}
Therapeutic monoclonal antibodies are among the most effective biotherapeutics to date. An important aspect of antibodies is their ability to bind antigen while at the same time recruit immune effector functions. The majority of approved recombinant monoclonal antibody therapies are of the human IgG1 subclass, which can engage both humoral and cellular components of the immune system. The wealth of information generated about antibodies has afforded investigators the ability to molecularly engineer antibodies to modulate effector functions. Here, we review various antibody engineering efforts intended to improve efficacy and safety relative to the human IgG isotype. Further, we will discuss proposed mechanisms by which engineering approaches led to modified interactions with immune components and provide examples of clinical studies using next generation antibodies.
\end{abstract}

KEYWORDS antibody-dependent cell-mediated cytotoxicity, antibody-dependent cellular phagocytosis, complement-dependent cytotoxicity, Fc engineering, Fc gamma receptor, monoclonal antibody, neonatal Fc receptor

\section{INTRODUCTION}

Antibodies are a critical component of the immune response, and the advent of the monoclonal antibody (mAb) technology has afforded the biotechnology and pharmaceutical industries the ability to develop antibodies as drugs. The success of mAb-based therapies is based on their safety, selectivity, diversity, solubility, tolerability, stability, and long circulating half-life. This success is further exemplified by the fact that

Xinhua Wang and Mary Mathieu have contributed equally to this work. there are currently over 50 investigational antibodies undergoing evaluation in late-stage clinical trials (Reichert, 2017) and approved antibodies generate an annual market of over $\$ 60$ billion (Ecker et al., 2015).

To date, all of the currently approved antibodies are of the $\lg$ isotype, which is further divided into four subclasses in humans (i.e., IgG1, IgG2, IgG3, and IgG4) (Brezski and Georgiou, 2016; Lefranc, 2001). The structure of an IgG antibody is comprised of two antigen-binding Fab arms linked to a single $\mathrm{Fc}$ domain via the hinge region. This structural arrangement allows antibodies to link bound antigen with humoral and cellular components of the immune system. Engagement of the humoral immune response is governed, in large part, by interactions with $\mathrm{C} 1 \mathrm{q}$ and the initiation of a series of proteolytic events known as the complement cascade (Meyer et al., 2014). The cellular immune response occurs mostly due to the interactions between the antibody and Fc gamma receptors (FcyRs). There are 5 activating FcyRs: the high affinity FcyRI (HGNC:3613) that can bind to monovalent antibody, and the lower affinity FcyRlla (HGNC:3616) and Ilc (HGNC:15626), and FcyRIIla (HGNC:3619) and IIIb (HGNC:3620) that require avidity-based interactions. There is one inhibitory receptor: FcyRllb (HGNC:3618). Intracellular signaling through the activating receptors is modulated through the phosphorylation of immunoreceptor tyrosine-based activation motifs (ITAMs), which leads to effector functions such as antibody-dependent cell-mediated cytotoxicity (ADCC), antibody-dependent cellular phagocytosis (ADCP), and inflammation via the induction of cytokine secretion. In contrast, intracellular signaling through the inhibitory FcyRIlb is modulated through the phosphorylation of immunoreceptor tyrosine-based inhibitory motifs (ITIMs), which recruit phosphatases that counter-balance activating signaling pathways (Nimmerjahn and Ravetch, 2008). Antibody interactions with FcyRs and $\mathrm{C} 1 \mathrm{q}$ are dependent on the hinge and proximal $\mathrm{CH} 2$ amino acid sequence as well as glycosylation 
Table 1. Examples of modifications to modulate antibody effector function. Unless otherwise noted, the mutations are on the IgG1 subclass.

\begin{tabular}{|c|c|c|}
\hline $\begin{array}{l}\text { Engineering and intended } \\
\text { function }\end{array}$ & Mutation & Reference \\
\hline \multicolumn{3}{|l|}{ Enhance ADCC } \\
\hline Increased FcyRIIla binding & F243L/R292P/Y300L/N305I/P396L & (Stavenhagen et al., 2007) \\
\hline Increased FcyRIIla binding & S239D/I332E & (Lazar et al., 2006) \\
\hline $\begin{array}{l}\text { Increased FcyRIIla binding, } \\
\text { Decreased FcyRllb binding }\end{array}$ & S239D//332E/A330L & (Lazar et al., 2006) \\
\hline \multirow[t]{2}{*}{ Increased FcyRIIla binding } & S298A/E333A/K334A & (Shields et al., 2001) \\
\hline & $\begin{array}{l}\text { In one heavy chain: L234Y/L235Q/G236W/ } \\
\text { S239M/H268D/D270E/S298A } \\
\text { In the opposing heavy chain: D270E/ } \\
\text { K326D/A330M/K334E }\end{array}$ & (Mimoto et al., 2013a) \\
\hline \multicolumn{3}{|l|}{ Enhance ADCP } \\
\hline $\begin{array}{l}\text { Increased FcyRlla binding, } \\
\text { Increased FcyRIIla binding }\end{array}$ & G236A/S239D/I332E & (Richards et al., 2008) \\
\hline \multicolumn{3}{|l|}{ Enhance CDC } \\
\hline Increased C1q binding & K326W/E333S & (Idusogie et al., 2001) \\
\hline Increased C1q binding & S267E/H268F/S324T & (Moore et al., 2010) \\
\hline Increased C1q binding & $\operatorname{lgG} 1 / \lg \mathrm{G} 3$ cross subclass & (Natsume et al., 2008) \\
\hline Hexamerization & E345R/E430G/S440Y & (Diebolder et al., 2014) \\
\hline \multicolumn{3}{|l|}{ Reduce effector function } \\
\hline Aglycosylated & N297A or N297Q or N297G & $\begin{array}{l}\text { (Bolt et al., 1993; Leabman et al., 2013; Tao and } \\
\text { Morrison, 1989; Walker et al., 1989) }\end{array}$ \\
\hline Reduced FcyR and C1q binding & L235E & (Alegre et al., 1992) \\
\hline Reduced FcyR and C1q binding & IgG1: L234A/L235A; IgG4:F234A/L235A & (Xu et al., 2000) \\
\hline Reduced FcyR and C1q binding & lgG2/lgG4 cross isotype & (Rother et al., 2007) \\
\hline Reduced FcyR and C1q binding & IgG2: H268Q/V309L/A330S/P331S & (An et al., 2009) \\
\hline Reduced FcyR and C1q binding & $\begin{array}{l}\text { IgG2: V234A/G237A/P238S/H268A/ } \\
\text { V309L/ } \\
\text { A330S/P331S }\end{array}$ & (Vafa et al., 2014) \\
\hline \multicolumn{3}{|l|}{ Increase half-life } \\
\hline $\begin{array}{l}\text { Increased FcRn binding at } \mathrm{pH} \\
6.0\end{array}$ & M252Y/S254T/T256E & (Dall'Acqua et al., 2002) \\
\hline $\begin{array}{l}\text { Increased FcRn binding at } \mathrm{pH} \\
6.0\end{array}$ & M428L/N434S & (Zalevsky et al., 2010) \\
\hline \multicolumn{3}{|l|}{ Increased coengagement } \\
\hline Increased FcyRIlb binding & S267E/L328F & (Chu et al., 2008) \\
\hline $\begin{array}{l}\text { Increased FcyRIla binding, } \\
\text { Decreased FcyRIIla binding }\end{array}$ & N325S/L328F & (Shang et al., 2014) \\
\hline
\end{tabular}

at the conserved amino acid N297 (EU numbering (Edelman et al., 1969)) in the $\mathrm{CH} 2$ region (Fig. 1).

Although many antibody-based therapies have had clinical and commercial success, antibody-based therapeutics are often only effective in a subset of patients. Therefore, considerable effort has been put into fine-tuning the properties of antibodies in attempts to achieve efficacy in larger patient populations. Among the many efforts, one area of focus has been modulating the ability of antibodies to interact with the humoral and cellular components of the immune system through a process known as Fc engineering (Carter, 2006; Presta, 2008; Strohl, 2011). The purpose of this review is to detail Fc engineering efforts that modulate effector function, and where appropriate, provide examples of clinical 
Table 2. An alignment of the hinge, $\mathrm{CH} 2$, and $\mathrm{CH} 3$ region for human IgG1 according to IMGT unique numbering (http://www.imgt. org/IMGTScientificChart/Numbering/Hu_IGHGnber.html) and EU numbering is shown.

\begin{tabular}{|c|c|c|c|c|c|c|c|c|c|c|c|c|c|c|c|c|c|c|c|c|c|}
\hline \multicolumn{22}{|l|}{ Core Hinge } \\
\hline EU numbering & 226 & 227 & 228 & 229 & & & & & & & & & & & & & & & & & \\
\hline IMGT unique & 11 & 12 & 13 & 14 & & & & & & & & & & & & & & & & & \\
\hline \multirow[t]{2}{*}{ Human IgG1 } & C & $\mathrm{P}$ & $\mathrm{P}$ & C & & & & & & & & & & & & & & & & & \\
\hline & & & & & & & & & & & & & & & & & & & & & \\
\hline \multicolumn{22}{|l|}{ Lower Hinge } \\
\hline EU numbering & 230 & 231 & 232 & 233 & 234 & 235 & 236 & 237 & 238 & & & & & & & & & & & & \\
\hline IMGT unique & 15 & 1.6 & 1.5 & 1.4 & 1.3 & 1.2 & 1.1 & 1 & 2 & & & & & & & & & & & & \\
\hline \multirow[t]{2}{*}{ Human IgG1 } & $P$ & A & $\mathrm{P}$ & $E$ & $L$ & L & G & G & $P$ & & & & & & & & & & & & \\
\hline & & & & & & & & & & & & & & & & & & & & & \\
\hline \multicolumn{12}{|l|}{$\mathrm{CH} 3$ Region } & & & & & & & & & & \\
\hline EU numbering & 239 & 240 & 241 & 242 & 243 & 244 & 245 & 246 & 247 & 248 & 249 & 250 & 251 & 252 & 253 & 254 & 255 & 256 & 257 & 258 & 259 \\
\hline IMGT unique & 3 & 4 & 5 & 6 & 7 & 8 & 9 & 10 & 11 & 12 & 13 & 14 & 15 & 15.1 & 15.2 & 16 & 17 & 18 & 19 & 20 & 21 \\
\hline Human IgG1 & S & V & $F$ & $\mathrm{~L}$ & $\mathrm{~F}$ & $P$ & $\mathrm{P}$ & K & $P$ & K & $D$ & $\mathrm{~T}$ & $\mathrm{~L}$ & $M$ & 1 & $S$ & $\mathrm{R}$ & $T$ & $P$ & $E$ & V \\
\hline \multicolumn{22}{|l|}{$\mathrm{CH} 2$ Region } \\
\hline EU numbering & 260 & 261 & 262 & 263 & 264 & 265 & 266 & 267 & 268 & 269 & 270 & 271 & 272 & 273 & 274 & 275 & 276 & 277 & 278 & 279 & 280 \\
\hline IMGT unique & 22 & 23 & 24 & 25 & 26 & 27 & 28 & 29 & 30 & 31 & 34 & 35 & 36 & 37 & 38 & 39 & 40 & 41 & 42 & 43 & 44 \\
\hline Human IgG1 & $\mathrm{T}$ & C & V & V & V & $D$ & V & $S$ & $\mathrm{H}$ & $E$ & $D$ & $P$ & $E$ & V & K & $\mathrm{F}$ & $N$ & W & $Y$ & V & D \\
\hline & & & & & & & & & & & & & & & & & & & & & \\
\hline \multicolumn{22}{|l|}{$\mathrm{CH} 2$ Region } \\
\hline EU numbering & 281 & 282 & 283 & 284 & 285 & 286 & 287 & 288 & 289 & 290 & 291 & 292 & 293 & 294 & 295 & 296 & 297 & 298 & 299 & 300 & 301 \\
\hline IMGT unique & 45 & 45.1 & 45.2 & 45.3 & 45.4 & 77 & 78 & 79 & 80 & 81 & 82 & 83 & 84 & 84.1 & 84.2 & 84.3 & 84.4 & 85.4 & 85.3 & 85.2 & 85.1 \\
\hline Human IgG1 & G & V & $E$ & V & $\mathrm{H}$ & $\mathrm{N}$ & A & $\mathrm{K}$ & $T$ & K & $P$ & $\mathrm{R}$ & $E$ & $E$ & $Q$ & $Y$ & $\mathrm{~N}$ & $S$ & $\mathrm{~T}$ & Y & $\mathrm{R}$ \\
\hline & & & & & & & & & & & & & & & & & & & & & \\
\hline $\mathrm{CH} 2$ Region & & & & & & & & & & & & & & & & & & & & & \\
\hline EU numbering & 302 & 303 & 304 & 305 & 306 & 307 & 308 & 309 & 310 & 311 & 312 & 313 & 314 & 315 & 316 & 317 & 318 & 319 & 320 & 321 & 322 \\
\hline IMGT unique & 85 & 86 & 87 & 88 & 89 & 90 & 91 & 92 & 93 & 94 & 95 & 96 & 97 & 98 & 99 & 100 & 101 & 102 & 103 & 104 & 105 \\
\hline Human IgG1 & V & V & $S$ & V & $L$ & $\mathrm{~T}$ & V & $\mathrm{L}$ & $\mathrm{H}$ & $Q$ & $D$ & W & $\mathrm{L}$ & $N$ & G & $K$ & $E$ & Y & $K$ & C & $K$ \\
\hline $\mathrm{CH} 2$ Region & & & & & & & & & & & & & & & & & & & & & \\
\hline EU numbering & 323 & 324 & 325 & 326 & 327 & 328 & 329 & 330 & 331 & 332 & 333 & 334 & 335 & 336 & 337 & 338 & 339 & 340 & & & \\
\hline IMGT unique & 106 & 107 & 108 & 109 & 110 & 113 & 114 & 115 & 116 & 117 & 118 & 119 & 120 & 121 & 122 & 123 & 124 & 125 & & & \\
\hline Human IgG1 & V & $S$ & $\mathrm{~N}$ & $\mathrm{~K}$ & A & $L$ & $\mathrm{P}$ & A & $\mathrm{P}$ & 1 & $E$ & $\mathrm{~K}$ & $T$ & I & S & $\mathrm{K}$ & A & K & & & \\
\hline & & & & & & & & & & & & & & & & & & & & & \\
\hline $\mathrm{CH} 3$ Region & & & & & & & & & & & & & & & & & & & & & \\
\hline EU numbering & 341 & 342 & 343 & 344 & 345 & 346 & 347 & 348 & 349 & 350 & 351 & 352 & 353 & 354 & 355 & 356 & 357 & 358 & 359 & 360 & 361 \\
\hline IMGT unique & 1.4 & 1.3 & 1.2 & 1.1 & 1 & 2 & 3 & 4 & 5 & 6 & 7 & 8 & 9 & 10 & 11 & 12 & 13 & 14 & 15 & 16 & 17 \\
\hline Human IgG1 & G & $Q$ & $\mathrm{P}$ & $R$ & $E$ & $\mathrm{P}$ & $Q$ & V & $Y$ & $\mathrm{~T}$ & $\mathrm{~L}$ & $\mathrm{P}$ & $\mathrm{P}$ & $S$ & $\mathrm{R}$ & D & $E$ & L & $T$ & K & $\mathrm{N}$ \\
\hline & & & & & & & & & & & & & & & & & & & & & \\
\hline CH3 Region & & & & & & & & & & & & & & & & & & & & & \\
\hline EU numbering & 362 & 362 & 364 & 365 & 366 & 367 & 368 & 369 & 370 & 371 & 372 & 373 & 374 & 375 & 376 & 377 & 378 & 379 & 380 & 381 & 382 \\
\hline IMGT unique & 18 & 19 & 20 & 21 & 22 & 23 & 24 & 25 & 26 & 27 & 28 & 29 & 30 & 35 & 36 & 37 & 38 & 39 & 40 & 41 & 42 \\
\hline Human IgG1 & $Q$ & V & $S$ & $\mathrm{~L}$ & $\mathrm{~T}$ & C & $\mathrm{L}$ & V & $K$ & G & $F$ & $\mathrm{Y}$ & $\mathrm{P}$ & $S$ & $D$ & 1 & A & V & $E$ & W & $E$ \\
\hline CH3 Region & & & & & & & & & & & & & & & & & & & & & \\
\hline EU numbering & 383 & 384 & 385 & 386 & 387 & 388 & 389 & 390 & 391 & 392 & 393 & 394 & 395 & 396 & 397 & 398 & 399 & 400 & 401 & 402 & 403 \\
\hline IMGT unique & 43 & 44 & 45 & 45.1 & 45.2 & 45.3 & 45.4 & 77 & 78 & 79 & 80 & 81 & 82 & 83 & 84 & 84.1 & 84.2 & 84.3 & 84.4 & 85.4 & 85.3 \\
\hline Human IgG1 & $S$ & $\mathrm{~N}$ & G & Q & $\mathrm{P}$ & $E$ & $\mathrm{~N}$ & $\mathrm{~N}$ & $Y$ & K & $\mathrm{T}$ & $\mathrm{T}$ & $\mathrm{P}$ & $P$ & V & $\mathrm{L}$ & D & $S$ & $D$ & G & $S$ \\
\hline & & & & & & & & & & & & & & & & & & & & & \\
\hline $\mathrm{CH} 3$ Region & & & & & & & & & & & & & & & & & & & & & \\
\hline EU numbering & 404 & 405 & 406 & 407 & 408 & 409 & 410 & 411 & 412 & 413 & 414 & 415 & 416 & 417 & 418 & 419 & 420 & 421 & 422 & 423 & 424 \\
\hline IMGT unique & 85.2 & 85.1 & 85 & 86 & 87 & 88 & 89 & 90 & 91 & 92 & 93 & 94 & 95 & 96 & 97 & 98 & 99 & 100 & 101 & 102 & 103 \\
\hline Human IgG1 & $\mathrm{F}$ & $\mathrm{F}$ & L & $Y$ & S & K & $\mathrm{L}$ & $T$ & V & $D$ & $\mathrm{~K}$ & S & $\mathrm{R}$ & W & $Q$ & $Q$ & G & $N$ & V & $\mathrm{F}$ & S \\
\hline & & & & & & & & & & & & & & & & & & & & & \\
\hline $\mathrm{CH} 3$ Region & & & & & & & & & & & & & & & & & & & & & \\
\hline EU numbering & 425 & 426 & 427 & 428 & 429 & 430 & 431 & 432 & 433 & 434 & 435 & 436 & 437 & 438 & 439 & 440 & 441 & 442 & 443 & 444 & 445 \\
\hline IMGT unique & 104 & 105 & 106 & 107 & 108 & 109 & 110 & 112 & 113 & 114 & 115 & 116 & 117 & 118 & 119 & 120 & 121 & 122 & 123 & 124 & 125 \\
\hline Human IgG1 & C & $S$ & V & $M$ & $\mathrm{H}$ & $E$ & A & $\mathrm{L}$ & $\mathrm{H}$ & $\mathrm{N}$ & $\mathrm{H}$ & Y & $T$ & $Q$ & K & $S$ & $\mathrm{~L}$ & $S$ & L & $S$ & $\mathrm{P}$ \\
\hline & & & & & & & & & & & & & & & & & & & & & \\
\hline CH3 Region & & & & & & & & & & & & & & & & & & & & & \\
\hline EU numbering & 446 & 447 & & & & & & & & & & & & & & & & & & & \\
\hline IMGT unique & 129 & 130 & & & & & & & & & & & & & & & & & & & \\
\hline Human IgG1 & G & K & & & & & & & & & & & & & & & & & & & \\
\hline
\end{tabular}

Note: The core hinge region is defined by the $\mathrm{N}$-terminal and C-terminal cysteines that link the two heavy chains together (Liu and May, 2012). The lower hinge region ends with the final amino acid prior to the start of the first $\mathrm{CH} 2 \beta$-sheet domain (as shown in PDBID: 3AVE, 1HZH, $5 \mathrm{KD} 3$, and $4 \mathrm{HAG})$. The red, green, and blue coloring scheme is the same that was used in Fig. 1. 
studies where Fc engineered antibodies have been employed.

\section{ENHANCED COMPLEMENT-BASED EFFECTOR FUNCTION}

Several approved antibodies have demonstrated potent in vitro CDC activity such as the anti-CD20 mAbs rituximab and ofatumumab (Teeling et al., 2006), and there are numerous ways that investigators have utilized Fc engineering to enhance complement-based effector function (Table 1). Idusogie et al. demonstrated that K326W/E333S enhanced $\mathrm{C} 1 \mathrm{q}$ binding and CDC activity relative to an $\lg \mathrm{G} 1$, leading the authors to suggest that these two residues play a structural role in interactions between $\mathrm{C} 1 \mathrm{q}$ and $\lg \mathrm{G}$ (Idusogie et al., 2001). Moore et al. demonstrated that the Fc mutations S267E/H268F/S324T enhanced C1q binding 47-fold and CDC activity 6.9-fold over IgG1 (Moore et al., 2010). The authors suggested that the S267E mutant altered the charge of the $\mathrm{Fc}$, potentially increasing ionic interactions with the C1q subunit $B$. Among the four human IgG subclasses, IgG3 has the most potent CDC activity (Tao et al., 1993). However, there are no approved $\lg \mathrm{G} 3$ therapeutics due in part to the relatively short half-life of $\lg \mathrm{G} 3$ as well as bioprocessing issues associated with IgG3's long hinge region (Brezski and Georgiou, 2016). To overcome the liabilities associated with lgG3, Natsume et al. generated a cross IgG subclass variant combining the $\mathrm{CH} 1$ and hinge regions of $\mathrm{IgG} 1$ with the $\mathrm{CH} 2$ and $\mathrm{CH} 3$ regions of IgG3 (Natsume et al., 2008), which resulted in up to 50 -fold enhanced $C D C$ activity relative to IgG1 depending on the cell line used to assess CDC activity. This enhanced activity may be attributable to the differences between $\lg \mathrm{G} 1$ and $\operatorname{lgG} 3$ in the $\mathrm{CH} 2$ region (i.e., K274Q/ N276K/Y300F), which are structurally proximal to the residues D270/K322/P329/P331 deemed critical for C1q interactions (Idusogie et al., 2000; Thommesen et al., 2000). Diebolder et al. employed an approach where they engineered the Fc region with the mutations E345R/E430G/ S440Y, which resulted in preformed IgG hexamers (Diebolder et al., 2014) and enhanced CDC activity. Structural data indicated that the hexamer oriented K322 in a position where it could favorably accommodate interactions with the hexameric $\mathrm{C} 1 \mathrm{q}$ headpiece. Together, these studies demonstrated that several different mutational approaches can enhance $\mathrm{C} 1 \mathrm{q}$ binding and the resultant $\mathrm{CDC}$ activity.

\section{ENGINEERING FOR FcYR-BASED EFFECTOR FUNCTION}

Early studies defining key amino acid binding sites on IgGs for FcyRs were performed by mutational analyses, and it was determined that the lower hinge and proximal $\mathrm{CH} 2$ regions were critical (Burton et al., 1988; Canfield and Morrison, 1991; Chappel et al., 1991; Duncan et al., 1988; Hulett et al., 1994; Jefferis et al., 1990; Lund et al., 1991; Partridge et al., 1986; Shields et al., 2001; Tamm et al., 1996; Wines et al., 2000; Woof et al., 1986). Additionally, multiple cocrystal structures of human IgG1 Fc with the low affinity FcyRs have allowed high resolution mapping of the binding interfaces. A recurrent finding among the low affinity FcyRs was that P329 packs between two conserved tryptophan residues found in all of the FcyRs (Mimoto et al., 2013b; Radaev et al., 2001; Ramsland et al., 2011; Sondermann et al., 2000)—an interaction termed the "proline sandwich". More recently, there have been several reports of human IgG1 Fc co-crystals with the high affinity FcyRl (Kiyoshi et al., 2015; Lu et al., 2015; Oganesyan et al., 2015). A common feature among these structures was that a hydrophobic pocket on the surface of FcyRI well-accommodated L235 on the Fc. Together, these mutational studies and crystal structures have resulted in a wealth of knowledge about how IgGs interact with their respective FcyRs.

The efficacy of several anti-cancer mAbs is thought to rely, in part, on recruitment of FcyR-based effector functions. This includes activation of NK cells via FcyRIlla and resultant $A D C C$ and inflammatory cytokine release, macrophage-mediated ADCP through interactions with multiple FcyRs, and recruitment and activation of other immune cells (e.g., neutrophils). For FcyRllla, the key receptor for NK cell-mediated ADCC, there are two polymorphic variants: V158 with higher affinity for $\operatorname{lgG} 1$, and F158 that has lower affinity for lgG1. The potential significance of these polymorphisms was reported in several clinical trials where cancer patients with the high-affinity V158 polymorphism showed better outcomes from cetuximab (Bibeau et al., 2009), trastuzumab (Gavin et al., 2017), and rituximab (Cartron et al., 2002) therapy compared to patients with the low-affinity F158 polymorphism, although there were also clinical trials where there was no apparent benefit from expressing the high affinity polymorphism. Due to the potential benefits of augmenting binding to FcyRs and the resultant enhanced innate immune cell function, investigators have utilized multiple approaches to engineer mAbs including glyco-engineering and mutating amino acids within the Fc region.

\section{Glyco-engineering}

IgGs contain a conserved glycosylation site at amino acid N297 in the $\mathrm{CH} 2$ domain. The core structure of the glycan is comprised of $\mathrm{N}$-acetylglucosamine (GlcNAc) and mannose, where additional modifications can include bisecting GlcNAc, fucose, galactose, and sialic acid. One of the first reports linking glycoengineering with enhanced $\mathrm{Fc}$ effector function demonstrated that $\lg$ G1 antibodies produced in a Chinese hamster ovary $(\mathrm{CHO})$ cell line expressing b $(1,4)-\mathrm{N}$-acetylglucosaminyltransferase III to express bisecting GICNAc augmented ADCC activity relative to IgG1 (Umana et al., 1999). A study by Shields et al. demonstrated that lgG1s deficient in fucose had an up to 50 -fold increase in FcyRIlla binding relative to $\lg \mathrm{G} 1$ as well as enhanced ADCC (Shields et al., 2002). Shinkawa et al. later demonstrated that fucose deficient antibodies had improved ADCC function 
compared to antibodies containing bisecting GlcNAc (Shinkawa et al., 2003). The putative mechanism for enhanced interactions between afucosylated antibodies and FcyRIIla was shown in a crystallographic study (Ferrara et al., 2011). Amino acid N162 in FcyRIIla contains a glycan, and the absence of fucose allows greater carbohydrate-carbohydrate interactions with the Fc, which increases the overall binding strength. At present, there are two glyco-engineered antibodies that have been approved, the anti-CD20 mAb, obinutuzumab, and the anti-CCR4 mAb, mogamulizumab (Beck and Reichert, 2012). These two antibodies demonstrate that glyco-engineering for enhanced effector function can translate into clinically approved therapeutics.

\section{Amino acid mutations}

There are several ways in which investigators have mutated the amino acid sequence of the $\operatorname{lgG} \mathrm{Fc}$ region to modulate FcyR- based effector function. Some examples include point mutations, design algorithms, yeast display, and asymmetric engineering. The results from each of these different technologies have yielded numerous mutations that modify Fc-FcyR interactions and the resultant effector functions (Table 1).

Shields et al. performed single alanine point mutations of all solvent-exposed amino acids in $\mathrm{CH} 2$ and $\mathrm{CH} 3$ domains of human $\operatorname{lgG} 1$. They further demonstrated that combining several identified mutations (e.g., S298A/E333A/K334A) resulted in enhanced ADCC relative to IgG1 (Shields et al., 2001). Lazar et al. engineered a series of Fc variants with optimized Fcy receptor affinity using computational design algorithms and high-throughput screening. The authors identified S239D/I332E and S239D/I332E/A330L as two variants with enhanced ADCC activity (Lazar et al., 2006). A crystal structure of an Fc fragment with the mutations S239D/A330L/I332E was solved and modeling studies suggested that additional hydrogen bonds, hydrophobic

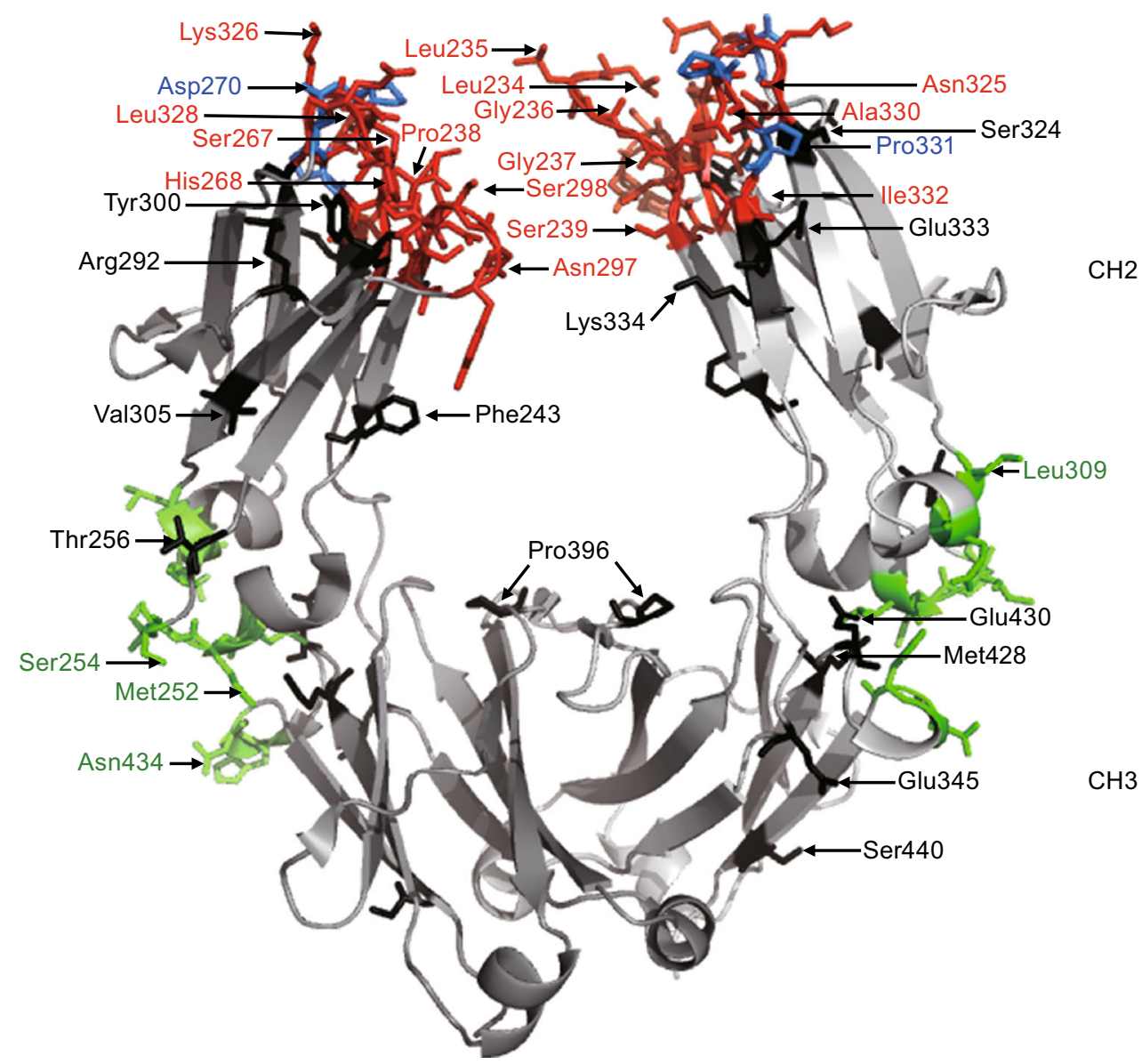

Figure 1. The Fc domain of human IgG1 is shown (PDBID:3AVE). The positions of amino acids described in Table 1 are shown. Key sequence motifs for FcRn interactions are shown in green (L251-S254; L309-Q311; N434-H435) (Oganesyan et al., 2014). Amino acids 5 angstroms proximal to the FcyR:Fc interface for FcyRI (PDBID:4W4O) (Kiyoshi et al., 2015), FcyRIla (PDBID:3RY6) (Ramsland et al., 2011), FcyRllb (PDBID:3WJJ) (Mimoto et al., 2013b), and FcyRIIlb (PDBID:1E4K) (Sondermann et al., 2000) as determined with PyMOL are shown in red (P232-S239; D265-D270; Y296-T299; N325-I332). The amino acids that are critical for interactions with C1q are shown in blue (D270, K322, P329, P331) (Idusogie et al., 2000). Amino acids depicted in black were not identified as critical for interactions with FyRs, FcRn, or C1q. Figure 1 was generated with PyMOL. 
contacts, and/or electrostatic interactions resulted in enhanced binding to FcyRIlla (Oganesyan et al., 2008). Richards demonstrated that the addition of G236A to the S239D/I332E mutations resulted in up to 70-fold improved binding to FcyRlla, a 13-fold improvement in the FcyRlla/ FcyRllb binding ratio (activating/inhibitory ratio), and enhanced phagocytosis of antibody-coated target cells by macrophages (Richards et al., 2008). Stavenhagen et al. utilized yeast surface display to identify the variant F243L/ R292P/Y300L/V305I/P396L, which showed >100 fold increased ADCC activity (Stavenhagen et al., 2007). Margetuximab, an anti-HER2 mAb with these 5 mutations completed a phase I clinical trial for patients with HER2overexpressing carcinomas (Bang et al., 2017). Mimoto et al. designed antibody variants with an asymmetrically engineered Fc domain by introducing different amino acid changes in each Fc domain. They screened $\sim 1000$ variants and demonstrated that L234Y/L235Q/G236W/S239M/ $\mathrm{H} 268 \mathrm{D} / \mathrm{D} 270 \mathrm{E} / \mathrm{S} 298 \mathrm{~A}$ changes in one $\mathrm{Fc}$ domain and $\mathrm{D} 270 \mathrm{E} / \mathrm{K} 326 \mathrm{D} / \mathrm{A} 330 \mathrm{M} / \mathrm{K} 334 \mathrm{E}$ changes in the other increased affinity for FcyRIIla F158 by more than 2000-fold and FcyRIIla V158 by more than 1000-fold (Mimoto et al., 2013a). Together, these investigations demonstrate that various technologies can be employed to obtain $\mathrm{Fc}$ variants with enhanced FcyR-dependent effector function.

\section{FC ENGINEERING FOR REDUCED EFFECTOR FUNCTION}

For cases where mAbs are intended to engage cell surface receptors and prevent receptor-ligand interactions (i.e., antagonists), it may be desirable to reduce or eliminate effector function for example to prevent target cell death or unwanted cytokine secretion. Other examples where reduced effector function may be warranted include preventing antibody-drug conjugates from interacting with FcyRs leading to off-target cytotoxicity (Uppal et al., 2015). The need for reducing or eliminating effector function was recognized with the first approved $m A b$, the murine IgG2a anti-CD3 $\varepsilon$ mAb, OKT3, muromonab, which was intended to prevent $\mathrm{T}$ cell activation in tissue transplant patients receiving a donor kidney, lung, or heart (Chatenoud and Bluestone, 2007). Many patients receiving muromonab had adverse events including the induction of pro-inflammatory cytokines (i.e., cytokine storm), which was attributed in part to muromonab's interactions with FcyRs (Alegre et al., 1992). In order to reduce this unintended effector function, Bluestone and colleagues generated the human lgG4 variant L235E (Alegre et al., 1992) or F234A/L235A (Xu et al., 2000), and the human IgG1 variant L234A/L235A (Xu et al., 2000), all of which reduced inflammatory cytokine release.

Another early approach intended to reduce effector function was to mutate the glycosylation site at N297 with mutations such as N297A, N297Q, and N297G (Bolt et al., 1993; Leabman et al., 2013; Tao and Morrison, 1989; Walker et al.,
1989). This aglycosylation approach has proven successful in abrogating Fc interactions with the low affinity FcyRs and effector functions such as CDC and ADCC. However, it was recognized early on that under avidity-based binding conditions, afucosylated IgGs have been shown to retain effector function when monocytes were employed as effector cells (Bolt et al., 1993). More recently, it was demonstrated that aglycosylated IgG1 mAbs had macrophage-mediated ADCP similar to lgG1 in the absence of competing serum via interactions with FcyRI (Lo et al., 2017; Nesspor et al., 2012). However, in the presence of $10 \%$ serum, the aglycosylated IgG1 had undetectable ADCP activity, suggesting that aglycosylated IgGs would have reduced effector function in circulation, which has serum IgG levels ranging from 10 to 20 $\mathrm{mg} / \mathrm{mL}$ (Nesspor et al., 2012).

Among the four IgG subclasses, each has a different ability to elicit immune effector functions. For instance, IgG1 and IgG3 have been recognized to recruit complement more effectively than IgG2 and lgG4 (Tao et al., 1993). Additionally, IgG2 and IgG4 have very limited ability to elicit ADCC (Brezski et al., 2014). Therefore, several investigators have employed a cross-subclass approach to reduce effector function. The approved anti-C5 therapeutic, eculizumab, has the IgG2 amino acids 118 to 260 and the IgG4 amino acids 261 to 447 and has been shown to have limited or undetectable effector function (Rother et al., 2007). As such, eculizumab represents the first proof-of-concept that reduced effector function mAbs can be safely utilized in an approved mAb-based therapeutic. In a further refinement of the cross-subclass approach, An et al. generated an IgG2 variant with point mutations from IgG4 (i.e., H268Q/V309L/A330S/P331S). This variant had reduced effector function as well as a circulating half-life comparable to that of lgG1 in rhesus monkeys (An et al., 2009). In a similar approach, a variant was reported that contained the $\lg$ G2 to $\lg 44$ cross-subclass mutations V309L/A330S/P331S combined with the non-germline mutations V234A/G237A/P238S/H268A, which resulted in undetectable CDC, ADCC, and ADCP (Vafa et al., 2014). The crystal structure of the mutated $\mathrm{Fc}$ was solved and modeling studies suggested that conformational changes at P329 would not be favorable for formation of the "proline sandwich" and changes at D270 could negatively impact $\mathrm{C} 1 \mathrm{q}$ interactions. Together, these studies demonstrate the numerous approaches that can be taken to reduce or eliminate effector function in hope of improving the safety of mAb therapeutics.

\section{FC ENGINEERING FOR COENGAGEMENT OF ANTIGEN AND FcyRS}

There are some cases where a potential therapeutic mAb's target antigen is found on cells that also express FcyRs. Chu et al. engineered a variant to capitalize on such a situation by augmenting binding to FcyRIlb, the primary Fc receptor 
expressed on B cells. The variant S267E/L328F has greater than 400-fold increased binding to FcyRllb compared to IgG1 (Chu et al., 2008). Szili et al. showed that coengagement of CD19 and FcyRllb with a mAb containing the S267E/L328F variant resulted in FcyRIIb ITIM phosphorylation, recruitment of $\mathrm{SH} 2$ domain-containing inositol polyphosphate 5-phosphatase (SHIP), and inhibition of downstream signaling pathways in B cells (e.g., Akt) (Szili et al., 2014). In contrast to utilizing coengagement of antigen with the inhibitory FcyRIlb, there are situations where antigen and FcyR coengagement can dramatically increase $\mathrm{mAb}$ potency through avidity-based interactions. Loyau et al. showed that a full length IgG1 anti-TLR4 mAb was 1000-fold more potent than the $F\left(a b^{\prime}\right)_{2}$ fragment version (Loyau et al., 2014). This was attributable to the Fab arms engaging TLR4 while the Fc simultaneously engaged FcyRI on the same cell. Coengagement of TLR4 and FcyRlla resulted in increased potency (i.e., half maximal inhibitory concentration), but to a lesser effect ( 25-fold). The antibody was engineered with two Fc mutations, N325S/L328F, which enhanced binding to FcyRlla (Shang et al., 2014). The Fc engineered anti-TLR4 mAb has completed phase I clinical trials (Monnet et al., 2017).

One consideration for engineering mAbs for coengagement of antigen with FcyRs is the induction of FcyR signaling pathways. For the S267E/L328F variant, engagement of FcyRIIb ITIM signaling was intended (Chu et al., 2008). However, for other receptors such as FcyRlla, not only is there the potential to engage ITAM signaling, there is also the possibility to engage inhibitory ITAM (ITAMi) signalingan event where instead of recruiting kinases, the ITAM recruits phosphatases (Blank et al., 2009). Shang et al. tested if the anti-TLR4 mAb engaged ITAMi signaling and showed that there was no activation of Src homology 2 domain containing protein tyrosine phosphatase (SHP-1) (Shang et al., 2014). Novel cases where coengagement is employed should assess downstream ITIM, ITAM, and ITAMi signaling pathways to determine whether or not the antibodies engage unintended signaling events.

\section{FCRN ENGINEERING TO ALTER HALF-LIFE}

The neonatal Fc receptor (FcRn) is a MH1Like heterodimer consisting of a major histocompatibility $\mathrm{MH} 1 \mathrm{Like}$ alpha chain non-covalently associated with beta-2-microglobulin $(\beta 2 \mathrm{~m})$ (Burmeister et al., 1994a) that plays a central role in the cellular trafficking and serum half-life of IgGs (Rath et al., 2013). Its name originates from historical observations leading to the search for a receptor mediating the transfer of humoral immunity from mother to neonatal rats (Brambell, 1966). Research in the early 1960s supported a mechanism of IgG transport specifically involving the Fc region (Brambell, 1966; Brambell et al., 1964; Fahey and Robinson, 1963). It was postulated that a single receptor might control both the transport of $\lg$ during early life and the protection of IgG from catabolism later in life (Brambell et al., 1964). These studies led to the current understanding that the long circulating half-life of antibodies (7-21 days depending on the IgG subclass (Morell et al., 1970)) is attributed, in large part, to their ability to bind FcRn through the Fc. The role of FcRn in IgG homeostasis was further supported by genetic studies where $\beta 2 \mathrm{~m}$ knockout mice had lower levels of circulating IgG (Ghetie et al., 1996; Israel et al., 1996; Junghans and Anderson, 1996).

FcRn is primarily expressed within endosomes where it is capable of binding to IgG internalized through pinocytosis. Conserved histidine residues in the $\mathrm{CH} 2-\mathrm{CH} 3$ domains of IgG become protonated at acidic endosomal $\mathrm{pH}$ (6.0-6.5), driving $\mathrm{pH}$-dependent binding to the a-chain of FcRn. Subsequent recycling and release of IgG to the bloodstream at physiological $\mathrm{pH}(7.4)$ salvages the antibody from lysosomal degradation (Roopenian and Akilesh, 2007). Mutational and x-ray crystallographic analyses provided insights into the amino acids involved in the Fc:FcRn interaction (Burmeister et al., 1994b; Kim et al., 1999; Martin et al., 2001; Medesan et al., 1997). More recently, the first co-crystal structure of an engineered human Fc with human FcRn provided a molecular understanding of Fc:FcRn interactions (Oganesyan et al., 2014). Key contact positions on the Fc region with FcRn include L251, M252Y (one of the Fc mutations), I253, L309, H310, L314, Q311, and N434 (Fig. 1 and Table 2). The authors further implicated strong hydrogen bonding through $\mathrm{H} 310$ as critical for $\mathrm{pH}$ dependent binding. Indeed, mutation of this amino acid to any other amino acid (excluding cysteine) resulted in undetectable binding to FcRn at $\mathrm{pH}$ 6.0. These characterizations of Fc:FcRn interactions combined with understanding $\mathrm{pH}$ dependent Fc:FcRn interactions ignited interest in modulating the pharmacokinetic (PK) properties of therapeutic antibodies through FcRn-mediated recycling mechanisms. Mutations at various positions proximal to the $\mathrm{CH} 2-\mathrm{CH} 3$ interface have been engineered with the intent that prolonged serum half-life may benefit patients by lowering the therapeutic dose and/or frequency of administration and reducing the cost of care (Table 1).

Screening of a phage display Fc variant library identified mutations (e.g., M252Y/S254T/T256E-termed YTE) with enhanced binding to human FcRn at $\mathrm{pH} 6.0$ (Dall'Acqua et al., 2002). A later study demonstrated that the YTE variant had 10 -fold increased binding to human and cynomolgus $\mathrm{FcRn}$ at $\mathrm{pH}$ 6.0, which translated into a 4-fold increase in half-life in a cynomolgus PK study (Dall'Acqua et al., 2006). Crystal structure analysis indicated that the T256E mutation provided 2 novel salt bridges between the Fc and $\beta 2 \mathrm{~m}$ subunit of FcRn (Oganesyan et al., 2014). In another report, Zalesky et al. showed that the mutations M428L/N434S resulted in an 11-fold increase in affinity for human FcRn at pH 6.0 (Zalevsky et al., 2010). When human FcRn transgenic tumor-bearing mice were treated with either an antiEGFR antibody or an anti-VEGF antibody containing the M428L/N434S mutations, an increased reduction in tumor burden was observed compared with $\lg \mathrm{G} 1$ treated animals 
(Zalevsky et al., 2010). This was the first in vivo demonstration of improved anti-tumor activity resulting from an FcRn-dependent increase in half-life. It was postulated that the N434S mutation allowed additional hydrogen bonds with FcRn (Oganesyan et al., 2014), resulting in the increased binding. Overall, these cases demonstrated that increasing the affinity of $\mathrm{IgG}$ for $\mathrm{FcRn}$ at $\mathrm{pH} 6.0$ resulted in extended half-life and efficacy in pre-clinical studies.

Motavizumab-YTE, a humanized antibody targeting respiratory syncytial virus, is the first antibody engineered for FcRn mediated half-life extension to be tested in human subjects (Robbie et al., 2013). The results from this phase I clinical trial in healthy adults demonstrated a 2- to 4-fold increase in half-life relative to motavizumab IgG1 depending on the dose, which provided proof-of-concept that FcRn low $\mathrm{pH}$ enhancing modifications translated into increased halflife in humans.

\section{CONCLUSIONS}

As there are currently 70 phase III and 575 phase I/II antibody-based drugs in clinical trials (Strohl, 2017), competition for targets is increasing, and the need to differentiate antibodies is becoming imperative. The successful approval of the effector function modulated mAbs eculizumab, obinutuzumab, and mogamulizumab has demonstrated that altering effector function can be a clinically viable way to differentiate mAbs from standard human IgG subclasses. With an increasing number of Fc engineered mAbs progressing through clinical trials, it will be interesting to see if modulating antibody effector function leads to the next generation of approved mAb-based therapeutics.

\section{ACKNOWLEDGEMENTS}

The authors would like to thank Yee Seir (Sheil) Kee for critical comments.

\section{ABBREVIATIONS}

ADCC, antibody-dependent cell-mediated cytotoxicity; ADCP, antibody-dependent cellular phagocytosis; $\beta 2 \mathrm{~m}$, beta-2-microglobulin; $\mathrm{CDC}$, complement-dependent cytotoxicity; $\mathrm{CHO}$, Chinese hamster ovary; EGFR, epidermal growth factor; FcyR, Fc gamma receptor; FcRn, neonatal Fc receptor; ITAM, immunoreceptor tyrosine-based activation motif; ITAMi, inhibitory immunoreceptor tyrosine-based activation motif; ITIM, immunoreceptor tyrosine-based inhibitory motifs; mAb, monoclonal antibody; MHC, major histocompatibility; SHIP, SH2 domain-containing inositol polyphosphate 5-phosphatase; TLR, toll-like receptor; VEGF, vascular endothelial growth factor

\section{COMPLIANCE WITH ETHICS GUIDELINES}

Xinhua Wang is an employee of Genentech. Mary Mathieu is an employee of Genentech. Randall J. Brezski is an employee of Genentech.

\section{OPEN ACCESS}

This article is distributed under the terms of the Creative Commons Attribution 4.0 International License (http://creativecommons.org/ licenses/by/4.0/), which permits unrestricted use, distribution, and reproduction in any medium, provided you give appropriate credit to the original author(s) and the source, provide a link to the Creative Commons license, and indicate if changes were made.

\section{REFERENCES}

Alegre ML, Collins AM, Pulito VL, Brosius RA, Olson WC, Zivin RA, Knowles R, Thistlethwaite JR, Jolliffe LK, Bluestone JA (1992) Effect of a single amino acid mutation on the activating and immunosuppressive properties of a "humanized" OKT3 monoclonal antibody. J Immunol 148:3461-3468

An Z, Forrest G, Moore R, Cukan M, Haytko P, Huang L, Vitelli S, Zhao JZ, Lu P, Hua J et al (2009) IgG2m4, an engineered antibody isotype with reduced $\mathrm{Fc}$ function. MAbs 1:572-579

Bang YJ, Giaccone G, Im SA, Oh DY, Bauer TM, Nordstrom JL, Li H, Chichili GR, Moore PA, Hong S et al (2017) First-in-human phase 1 study of margetuximab (MGAH22), an Fc-modified chimeric monoclonal antibody, in patients with HER2-positive advanced solid tumors. Ann Oncol 28:855-861

Beck A, Reichert JM (2012) Marketing approval of mogamulizumab: a triumph for glyco-engineering. MAbs 4:419-425

Bibeau F, Lopez-Crapez E, Di Fiore F, Thezenas S, Ychou M, Blanchard F, Lamy A, Penault-Llorca F, Frebourg T, Michel P et al (2009) Impact of Fc\{gamma\}RIla-Fc\{gamma\}RIIla polymorphisms and KRAS mutations on the clinical outcome of patients with metastatic colorectal cancer treated with cetuximab plus irinotecan. J Clin Oncol 27:1122-1129

Blank U, Launay P, Benhamou M, Monteiro RC (2009) Inhibitory ITAMs as novel regulators of immunity. Immunol Rev 232:59-71

Bolt S, Routledge E, Lloyd I, Chatenoud L, Pope H, Gorman SD, Clark M, Waldmann H (1993) The generation of a humanized, non-mitogenic CD3 monoclonal antibody which retains in vitro immunosuppressive properties. Eur J Immunol 23:403-411

Brambell FW (1966) The transmission of immunity from mother to young and the catabolism of immunoglobulins. Lancet 2:10871093

Brambell FW, Hemmings WA, Morris IG (1964) A theoretical model of gamma-globulin catabolism. Nature 203:1352-1354

Brezski RJ, Georgiou G (2016) Immunoglobulin isotype knowledge and application to Fc engineering. Curr Opin Immunol 40:62-69

Brezski RJ, Kinder M, Grugan KD, Soring KL, Carton J, Greenplate AR, Petley T, Capaldi D, Brosnan K, Emmell E et al (2014) A monoclonal antibody against hinge-cleaved $\lg G$ restores effector function to proteolytically-inactivated IgGs in vitro and in vivo. MAbs 6:1265-1273

Burmeister WP, Gastinel LN, Simister NE, Blum ML, Bjorkman PJ (1994a) Crystal structure at 2.2 A resolution of the MHC-related neonatal Fc receptor. Nature 372:336-343

Burmeister WP, Huber AH, Bjorkman PJ (1994b) Crystal structure of the complex of rat neonatal Fc receptor with Fc. Nature 372:379383 
Burton DR, Jefferis R, Partridge LJ, Woof JM (1988) Molecular recognition of antibody (IgG) by cellular Fc receptor (FCRI). Mol Immunol 25:1175-1181

Canfield SM, Morrison SL (1991) The binding affinity of human IgG for its high affinity $\mathrm{Fc}$ receptor is determined by multiple amino acids in the $\mathrm{CH} 2$ domain and is modulated by the hinge region. J Exp Med 173:1483-1491

Carter PJ (2006) Potent antibody therapeutics by design. Nat Rev Immunol 6:343-357

Cartron G, Dacheux L, Salles G, Solal-Celigny P, Bardos P, Colombat P, Watier H (2002) Therapeutic activity of humanized anti-CD20 monoclonal antibody and polymorphism in IgG Fc receptor FcgammaRIIla gene. Blood 99:754-758

Chappel MS, Isenman DE, Everett M, Xu YY, Dorrington KJ, Klein $\mathrm{MH}$ (1991) Identification of the Fc gamma receptor class I binding site in human IgG through the use of recombinant IgG1/lgG2 hybrid and point-mutated antibodies. Proc Natl Acad Sci USA 88:9036-9040

Chatenoud L, Bluestone JA (2007) CD3-specific antibodies: a portal to the treatment of autoimmunity. Nat Rev Immunol 7:622-632

Chu SY, Vostiar I, Karki S, Moore GL, Lazar GA, Pong E, Joyce PF, Szymkowski DE, Desjarlais JR (2008) Inhibition of B cell receptor-mediated activation of primary human $\mathrm{B}$ cells by coengagement of CD19 and FcgammaRIlb with Fc-engineered antibodies. Mol Immunol 45:3926-3933

Dall'Acqua WF, Woods RM, Ward ES, Palaszynski SR, Patel NK, Brewah YA, Wu H, Kiener PA, Langermann S (2002) Increasing the affinity of a human IgG1 for the neonatal Fc receptor: biological consequences. J Immunol 169:5171-5180

Dall'Acqua WF, Kiener PA, Wu H (2006) Properties of human IgG1s engineered for enhanced binding to the neonatal $\mathrm{FC}$ receptor (FcRn). J Biol Chem 281:23514-23524

Diebolder CA, Beurskens FJ, de Jong RN, Koning RI, Strumane K, Lindorfer MA, Voorhorst M, Ugurlar D, Rosati S, Heck AJ et al (2014) Complement is activated by IgG hexamers assembled at the cell surface. Science 343:1260-1263

Duncan AR, Woof JM, Partridge LJ, Burton DR, Winter G (1988) Localization of the binding site for the human high-affinity $\mathrm{Fc}$ receptor on IgG. Nature 332:563-564

Ecker DM, Jones SD, Levine HL (2015) The therapeutic monoclonal antibody market. MAbs 7:9-14

Edelman GM, Cunningham BA, Gall WE, Gottlieb PD, Rutishauser U, Waxdal MJ (1969) The covalent structure of an entire gammaG immunoglobulin molecule. Proc Natl Acad Sci USA 63:78-85

Fahey JL, Robinson AG (1963) Factors controlling serum gammaglobulin concentration. J Exp Med 118:845-868

Ferrara C, Grau S, Jager C, Sondermann P, Brunker P, Waldhauer I, Hennig M, Ruf A, Rufer AC, Stihle M et al (2011) Unique carbohydrate-carbohydrate interactions are required for high affinity binding between FcgammaRIII and antibodies lacking core fucose. Proc Natl Acad Sci USA 108:12669-12674

Gavin PG, Song N, Kim SR, Lipchik C, Johnson NL, Bandos H, Finnigan M, Rastogi P, Fehrenbacher L, Mamounas EP et al (2017) Association of polymorphisms in FCGR2A and FCGR3A with degree of trastuzumab benefit in the adjuvant treatment of
ERBB2/HER2-positive breast cancer: analysis of the NSABP B-31 trial. JAMA Oncol 3:335-341

Ghetie V, Hubbard JG, Kim JK, Tsen MF, Lee Y, Ward ES (1996) Abnormally short serum half-lives of $\mathrm{IgG}$ in beta 2-microglobulindeficient mice. Eur J Immunol 26:690-696

Hulett MD, Witort E, Brinkworth RI, McKenzie IF, Hogarth PM (1994) Identification of the $\mathrm{IgG}$ binding site of the human low affinity receptor for IgG Fc gamma RII. Enhancement and ablation of binding by sitedirected mutagenesis. J Biol Chem 269:15287-15293

Idusogie EE, Presta LG, Gazzano-Santoro H, Totpal K, Wong PY, Ultsch M, Meng YG, Mulkerrin MG (2000) Mapping of the C1q binding site on rituxan, a chimeric antibody with a human $\operatorname{lgG} 1$ Fc. J Immunol 164:4178-4184

Idusogie EE, Wong PY, Presta LG, Gazzano-Santoro H, Totpal K, Ultsch M, Mulkerrin MG (2001) Engineered antibodies with increased activity to recruit complement. J Immunol 166:25712575

Israel EJ, Wilsker DF, Hayes KC, Schoenfeld D, Simister NE (1996) Increased clearance of IgG in mice that lack beta 2-microglobulin: possible protective role of FcRn. Immunology 89:573-578

Jefferis R, Lund J, Pound J (1990) Molecular definition of interaction sites on human IgG for Fc receptors (huFc gamma R). Mol Immunol 27:1237-1240

Junghans RP, Anderson CL (1996) The protection receptor for IgG catabolism is the beta2-microglobulin-containing neonatal intestinal transport receptor. Proc Natl Acad Sci USA 93:5512-5516

Kim JK, Firan M, Radu CG, Kim CH, Ghetie V, Ward ES (1999) Mapping the site on human IgG for binding of the MHC class I-related receptor, FcRn. Eur J Immunol 29:2819-2825

Kiyoshi M, Caaveiro JM, Kawai T, Tashiro S, Ide T, Asaoka Y, Hatayama K, Tsumoto K (2015) Structural basis for binding of human IgG1 to its high-affinity human receptor FcgammaRI. Nat Commun 6:6866

Lazar GA, Dang W, Karki S, Vafa O, Peng JS, Hyun L, Chan C, Chung HS, Eivazi A, Yoder SC et al (2006) Engineered antibody Fc variants with enhanced effector function. Proc Natl Acad Sci USA 103:4005-4010

Leabman MK, Meng YG, Kelley RF, DeForge LE, Cowan KJ, lyer S (2013) Effects of altered FcgammaR binding on antibody pharmacokinetics in cynomolgus monkeys. MAbs 5:896-903

Lefran MPL (2001) The immunoglobulin factsbook. Elsevier, Amsterdam

Liu H, May K (2012) Disulfide bond structures of IgG molecules: structural variations, chemical modifications and possible impacts to stability and biological function. MAbs 4:17-23

Lo M, Kim HS, Tong RK, Bainbridge TW, Vernes JM, Zhang Y, Lin YL, Chung S, Dennis MS, Zuchero YJ et al (2017) Effectorattenuating substitutions that maintain antibody stability and reduce toxicity in mice. J Biol Chem 292:3900-3908

Loyau J, Malinge P, Daubeuf B, Shang L, Elson G, Kosco-Vilbois M, Fischer N, Rousseau F (2014) Maximizing the potency of an antiTLR4 monoclonal antibody by exploiting proximity to Fcgamma receptors. MAbs 6:1621-1630

Lu J, Chu J, Zou Z, Hamacher NB, Rixon MW, Sun PD (2015) Structure of FcgammaRI in complex with Fc reveals the 
importance of glycan recognition for high-affinity IgG binding. Proc Natl Acad Sci USA 112:833-838

Lund J, Winter G, Jones PT, Pound JD, Tanaka T, Walker MR, Artymiuk PJ, Arata Y, Burton DR, Jefferis R et al (1991) Human Fc gamma RI and Fc gamma RII interact with distinct but overlapping sites on human IgG. J Immunol 147:26572662

Martin WL, West AP Jr, Gan L, Bjorkman PJ (2001) Crystal structure at $2.8 \mathrm{~A}$ of an $\mathrm{FcRn} /$ heterodimeric $\mathrm{Fc}$ complex: mechanism of $\mathrm{pH}$ dependent binding. Mol Cell 7:867-877

Medesan C, Matesoi D, Radu C, Ghetie V, Ward ES (1997) Delineation of the amino acid residues involved in transcytosis and catabolism of mouse IgG1. J Immunol 158:2211-2217

Meyer S, Leusen JH, Boross P (2014) Regulation of complement and modulation of its activity in monoclonal antibody therapy of cancer. MAbs 6:1133-1144

Mimoto F, Igawa T, Kuramochi T, Katada H, Kadono S, Kamikawa T, Shida-Kawazoe M, Hattori K (2013a) Novel asymmetrically engineered antibody Fc variant with superior FcgammaR binding affinity and specificity compared with afucosylated $\mathrm{Fc}$ variant. MAbs 5:229-236

Mimoto F, Katada H, Kadono S, Igawa T, Kuramochi T, Muraoka M, Wada Y, Haraya K, Miyazaki T, Hattori K (2013b) Engineered antibody Fc variant with selectively enhanced FcgammaRIlb binding over both FcgammaRIla(R131) and FcgammaRlla (H131). Protein Eng Des Sel 26:589-598

Monnet E, Lapeyre G, Poelgeest EV, Jacqmin P, Graaf K, Reijers J, Moerland M, Burggraaf J, Min C (2017) Evidence of NI-0101 pharmacological activity, an anti-TLR4 antibody, in a randomized phase I dose escalation study in healthy volunteers receiving LPS. Clin Pharmacol Ther 101:200-208

Moore GL, Chen H, Karki S, Lazar GA (2010) Engineered Fc variant antibodies with enhanced ability to recruit complement and mediate effector functions. MAbs 2:181-189

Morell A, Terry WD, Waldmann TA (1970) Metabolic properties of IgG subclasses in man. J Clin Invest 49:673-680

Natsume A, In M, Takamura H, Nakagawa T, Shimizu Y, Kitajima K, Wakitani M, Ohta S, Satoh M, Shitara K et al (2008) Engineered antibodies of $\operatorname{lgG} 1 / \lg 33$ mixed isotype with enhanced cytotoxic activities. Cancer Res 68:3863-3872

Nesspor TC, Raju TS, Chin CN, Vafa O, Brezski RJ (2012) Avidity confers FcgammaR binding and immune effector function to aglycosylated immunoglobulin G1. J Mol Recognit 25:147-154

Nimmerjahn F, Ravetch JV (2008) Fcgamma receptors as regulators of immune responses. Nat Rev Immunol 8:34-47

Oganesyan V, Damschroder MM, Leach W, Wu H, Dall'Acqua WF (2008) Structural characterization of a mutated, ADCC-enhanced human Fc fragment. Mol Immunol 45:1872-1882

Oganesyan V, Damschroder MM, Cook KE, Li Q, Gao C, Wu H, Dall'Acqua WF (2014) Structural insights into neonatal Fc receptorbased recycling mechanisms. J Biol Chem 289:7812-7824

Oganesyan V, Mazor Y, Yang C, Cook KE, Woods RM, Ferguson A, Bowen MA, Martin T, Zhu J, Wu H et al (2015) Structural insights into the interaction of human IgG1 with FcgammaRI: no direct role of glycans in binding. Acta Crystallogr D 71:2354-2361
Partridge LJ, Woof JM, Jefferis R, Burton DR (1986) The use of antiIgG monoclonal antibodies in mapping the monocyte receptor site on IgG. Mol Immunol 23:1365-1372

Presta LG (2008) Molecular engineering and design of therapeutic antibodies. Curr Opin Immunol 20:460-470

Radaev S, Motyka S, Fridman WH, Sautes-Fridman C, Sun PD (2001) The structure of a human type III Fcgamma receptor in complex with Fc. J Biol Chem 276:16469-16477

Ramsland PA, Farrugia W, Bradford TM, Sardjono CT, Esparon S, Trist HM, Powell MS, Tan PS, Cendron AC, Wines BD et al (2011) Structural basis for Fc gammaRIla recognition of human IgG and formation of inflammatory signaling complexes. J Immunol 187:3208-3217

Rath T, Kuo TT, Baker K, Qiao SW, Kobayashi K, Yoshida M, Roopenian D, Fiebiger E, Lencer WI, Blumberg RS (2013) The immunologic functions of the neonatal Fc receptor for IgG. J Clin Immunol 33(Suppl 1):S9-17

Reichert JM (2017) Antibodies to watch in 2017. MAbs 9:167-181

Richards JO, Karki S, Lazar GA, Chen H, Dang W, Desjarlais JR (2008) Optimization of antibody binding to FcgammaRlla enhances macrophage phagocytosis of tumor cells. Mol Cancer Ther 7:2517-2527

Robbie GJ, Criste R, Dall'acqua WF, Jensen K, Patel NK, Losonsky GA, Griffin MP (2013) A novel investigational Fc-modified humanized monoclonal antibody, motavizumab-YTE, has an extended half-life in healthy adults. Antimicrob Agents Chemother 57:6147-6153

Roopenian DC, Akilesh S (2007) FcRn: the neonatal Fc receptor comes of age. Nat Rev Immunol 7:715-725

Rother RP, Rollins SA, Mojcik CF, Brodsky RA, Bell L (2007) Discovery and development of the complement inhibitor eculizumab for the treatment of paroxysmal nocturnal hemoglobinuria. Nat Biotechnol 25:1256-1264

Shang L, Daubeuf B, Triantafilou M, Olden R, Depis F, Raby AC, Herren S, Dos Santos A, Malinge P, Dunn-Siegrist I et al (2014) Selective antibody intervention of Toll-like receptor 4 activation through Fc gamma receptor tethering. J Biol Chem 289:15309-15318

Shields RL, Namenuk AK, Hong K, Meng YG, Rae J, Briggs J, Xie D, Lai J, Stadlen A, Li B et al (2001) High resolution mapping of the binding site on human IgG1 for Fc gamma RI, Fc gamma RII, Fc gamma RIII, and FcRn and design of IgG1 variants with improved binding to the Fc gamma R. J Biol Chem 276:65916604

Shields RL, Lai J, Keck R, O'Connell LY, Hong K, Meng YG, Weikert $\mathrm{SH}$, Presta LG (2002) Lack of fucose on human IgG1 N-linked oligosaccharide improves binding to human Fcgamma RIII and antibody-dependent cellular toxicity. J Biol Chem 277:2673326740

Shinkawa T, Nakamura K, Yamane N, Shoji-Hosaka E, Kanda Y, Sakurada M, Uchida K, Anazawa H, Satoh M, Yamasaki M et al (2003) The absence of fucose but not the presence of galactose or bisecting $\mathrm{N}$-acetylglucosamine of human $\operatorname{lgG} 1$ complex-type oligosaccharides shows the critical role of enhancing antibody-dependent cellular cytotoxicity. J Biol Chem 278:3466-3473 
Sondermann P, Huber R, Oosthuizen V, Jacob U (2000) The 3.2-A crystal structure of the human IgG1 Fc fragment-Fc gammaRIII complex. Nature 406:267-273

Stavenhagen JB, Gorlatov S, Tuaillon N, Rankin CT, Li H, Burke S, Huang L, Vijh S, Johnson S, Bonvini E et al (2007) Fc optimization of therapeutic antibodies enhances their ability to kill tumor cells in vitro and controls tumor expansion in vivo via low-affinity activating Fcgamma receptors. Cancer Res 67:8882-8890

Strohl WR (2011) Isotype selection and Fc engineering: design and construction of fit-for-purpose therapeutic antibodies. Antibody drug discovery Imperial College Press, London

Strohl WR (2017) Current progress in innovative engineered antibodies. Protein Cell. doi:10.1007/s13238-017-0457-8

Szili D, Cserhalmi M, Banko Z, Nagy G, Szymkowski DE, Sarmay G (2014) Suppression of innate and adaptive B cell activation pathways by antibody coengagement of FcgammaRIlb and CD19. MAbs 6:991-999

Tamm A, Kister A, Nolte KU, Gessner JE, Schmidt RE (1996) The IgG binding site of human FcgammaRIIIB receptor involves CC' and FG loops of the membrane-proximal domain. J Biol Chem 271:3659-3666

Tao MH, Morrison SL (1989) Studies of aglycosylated chimeric mouse-human $\mathrm{lgG}$. Role of carbohydrate in the structure and effector functions mediated by the human $\lg G$ constant region. $\mathrm{J}$ Immunol 143:2595-2601

Tao MH, Smith RI, Morrison SL (1993) Structural features of human immunoglobulin $\mathrm{G}$ that determine isotype-specific differences in complement activation. J Exp Med 178:661-667

Teeling JL, Mackus WJ, Wiegman LJ, van den Brakel JH, Beers SA, French RR, van Meerten T, Ebeling S, Vink T, Slootstra JW et al (2006) The biological activity of human CD20 monoclonal antibodies is linked to unique epitopes on CD20. J Immunol 177:362-371

Thommesen JE, Michaelsen TE, Loset GA, Sandlie I, Brekke OH (2000) Lysine 322 in the human $\lg G 3 \mathrm{C}(\mathrm{H}) 2$ domain is crucial for antibody dependent complement activation. Mol Immunol 37:995-1004

Umana P, Jean-Mairet J, Moudry R, Amstutz H, Bailey JE (1999) Engineered glycoforms of an antineuroblastoma $\operatorname{lgG} 1$ with optimized antibody-dependent cellular cytotoxic activity. Nat Biotechnol 17:176-180

Uppal H, Doudement E, Mahapatra K, Darbonne WC, Bumbaca D, Shen BQ, Du X, Saad O, Bowles K, Olsen S et al (2015) Potential mechanisms for thrombocytopenia development with trastuzumab emtansine (T-DM1). Clin Cancer Res 21:123-133

Vafa O, Gilliland GL, Brezski RJ, Strake B, Wilkinson T, Lacy ER, Scallon B, Teplyakov A, Malia TJ, Strohl WR (2014) An engineered $\mathrm{Fc}$ variant of an $\mathrm{IgG}$ eliminates all immune effector functions via structural perturbations. Methods 65:114-126

Walker MR, Lund J, Thompson KM, Jefferis R (1989) Aglycosylation of human $\lg \mathrm{G} 1$ and $\lg \mathrm{G} 3$ monoclonal antibodies can eliminate recognition by human cells expressing Fc gamma RI and/or Fc gamma RII receptors. Biochem J 259:347-353

Wines BD, Powell MS, Parren PW, Barnes N, Hogarth PM (2000) The IgG Fc contains distinct Fc receptor (FcR) binding sites: the leukocyte receptors Fc gamma RI and Fc gamma Rlla bind to a region in the $\mathrm{Fc}$ distinct from that recognized by neonatal $\mathrm{FcR}$ and protein A. J Immunol 164:5313-5318

Woof JM, Partridge LJ, Jefferis R, Burton DR (1986) Localisation of the monocyte-binding region on human immunoglobulin $\mathrm{G}$. Mol Immunol 23:319-330

Xu D, Alegre ML, Varga SS, Rothermel AL, Collins AM, Pulito VL, Hanna LS, Dolan KP, Parren PW, Bluestone JA et al (2000) In vitro characterization of five humanized OKT3 effector function variant antibodies. Cell Immunol 200:16-26

Zalevsky J, Chamberlain AK, Horton HM, Karki S, Leung IW, Sproule TJ, Lazar GA, Roopenian DC, Desjarlais JR (2010) Enhanced antibody half-life improves in vivo activity. Nat Biotechnol 28:157-159 